\title{
A hypothesis about the supply function in the tourist industry
}

\author{
F. Zaccaria ${ }^{1} \&$ C. Bizzarri ${ }^{2}$ \\ ${ }^{1}$ University San PioV of Rome, Italy \\ ${ }^{2}$ Sapienza University of Rome, Italy
}

\begin{abstract}
This paper deals with the supply function trend in the tourism industry. In this regard, Sraffa's theory is based on a strong link between a perfectly competitive system and supply at constant cost and consequently with stabile supply prices. The paper's purpose is to present an analysis of specific problems of the supply trend in the tourism industry. Brief research shows that the tourism industry has a decreasing trend. The supply function's character is due to internal economies and chiefly to external economies. An analysis on trends of the tourism industry proves that this sector of the economy operates in a system that is not of perfect competition but is characterized by imperfect or monopolistic competition. At a certain point of function we can remark on an opposite trend because the function begins to rise.
\end{abstract}

Keywords: supply function, tourism development, environmental quality, political economy.

\section{The Sraffian hypothesis of a constant supply function in a perfectly competitive market}

The trend of the supply function of an industry is a crucial problem for the contemporary economy. The theory of supply has been extensively discussed in Economics, which has developed explanatory hypotheses on several occasions. It is only worth mentioning here the distinction between a company and an industry, the former being an individual productive unit with its own supply function and the latter a sum of the companies existing on the market. Thus, all the companies form the industry as a whole, and the sum of the companies supply determines the supply of the industry. A fundamental assumption of the 
theory is that the supply price, i.e. the price at which the companies of an industry in an economic sector are willing to sell their goods or services, varies as a function of the produced quantity, according to the formula:

$$
\mathrm{P}^{\circ}=\mathrm{f}(\mathrm{Q})
$$

For a long time, recent and contemporary economic analyses have investigated the dynamics of the industrial supply price variation as a function of the produced quantity. A fundamental theoretical principle applied in Economics, and derived from Sraffa's formulation [1], sees an inevitable link between a perfectly competitive system and a supply with stable prices, as shown in the graph in Figure 1.

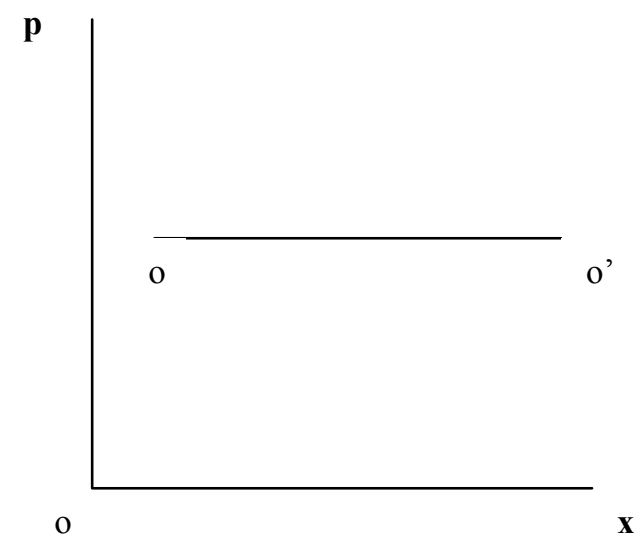

Figure 1: Supply function in a perfectly competitive system.

Sraffa's hypothesis has always exerted a strong fascination on economic scholars, as Caffè [2]. It is worth testing its applicability to the tourist sector where the existence of a universe with scattered companies, some of them small and others large, determines market conditions that may look similar to the competitive system.

\section{Tourist industry internal economies}

The tourist industry presents special features which causes large differences from general assumptions of theory.

An increase in industrial production might determine a series of economies within the productive units that can be explained with the model of internal economies (Kreps [3]). If production increases, the companies belonging to the industry use productive plants more extensively, dividing their fixed costs by a greater number of service units. For example, an enterprise that has had to bear high costs to build a hotel gets a reduction in the fixed costs for each unit of production if the services produced in the management period have doubled or 
tripled. If there is a growth in the productivity of the productive factors, the company can profit from these factors' increased efficiency. Nevertheless, the weight of internal economies in the tourist sector is less significant than it may appear at first sight: there are phenomena that come into play causing a decrease in the productivity of some productive factors and reducing the effect of internal economies (Palmerio [4]).

Furthermore, when examining the industry as a whole, we have to bear in mind that an increase in production requires the entry (into the sector) of new companies which have less productive efficiency than companies already operating in the same sector. As a consequence, the entry of these new firms either determines cost rises or counterbalances the internal economies produced by existing companies (Phelps [5]).

\section{External economies as a function of supplied quantities}

If internal economies play a minor role in determining the supply trend of the tourist industry, a major role is played by external economies. We can observe, in the tourism sector a tight link between large or small companies offering services and external factors. The different companies composing the industry operate in a complex context where the so called "tourist vocation" of the territory finds its realization, and the interaction between a company's action and external factors become manifest.

A rise in production determined by investments and by an increase in the number of companies belonging to the tourist industry triggers cost reduction external mechanisms. For example, individual enterprises can benefit from more appropriate, cheaper and wider network services. Indeed, if the public sector is responsive to the increase in production occurring in the tourist sector and supports the "tourist vocation" of the territory, it implements wide and efficient public service infrastructures. Moreover, tourist services are developed in an environment that determines a supply of more qualified and experienced labour. This supply is motivated by and aware of service quality requirements and consumers' demand for customized and high level services. In short, the development of the tourist sector contributes to the creation of human capital, which, in turn, develops external economies in the tourist industry. Tourist services quality depends in large measure on personnel attitude and training. In a country where a tourist sector is developing the old or the starting up companies may make use of better workers and higher quality services offered by other enterprises and by public sector.

\section{Tourist industry decreasing cost-supply}

On the basis of our observations and hypotheses, the price of the services supplied by the tourist industry as a whole reveals a decreasing trend as expressed by the function

$$
\mathrm{Y}=\mathrm{a}-\mathrm{bX}
$$




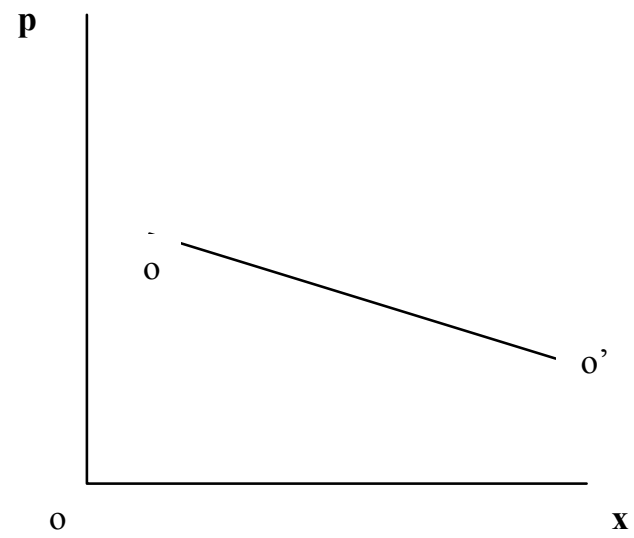

Figure 2: $\quad$ Supply function in tourist industry supply.

and shown in Figure 2, which highlights how, at a first approximation, the supply curve is negatively- sloped.

This makes an increase in the production of tourist services such as hotel accommodation more convenient because it allows cost reductions and offers a series of opportunities fostering employment development and economic growth. Moreover, the increase in production makes qualified accommodation services available at prices that tourists can afford.

When compared with Sraffa's theory, the supply trend of the tourist industry is likely to suggest the hypothesis that neither a competitive system nor a system somehow similar to the competitive one can exist in the tourist industry. Indeed, Sraffa's model is based on a system of perfect competition. We can notice that the tourist industry functions in a system which is more similar to imperfect or monopolistic competition. It deals with the production of highly differentiated and customized goods.

\section{Conclusion}

The decreasing trend of the tourist industry supply price is not unlimited (Alessandrini and Passarelli [6]): when a certain production level is surpassed, a series of diseconomies intervenes to compensate the productive factors of external and internal economies. First of all, the growth of tourist industry consumers causes phenomena of tourist service congestion. The presence of numerous hotel clients creates an excessive presence of tourists and maybe also crowds that cause inconveniences and diseconomies. A huge number of visitors to museums or landscape beauty spots increase costs. As far as external economies are concerned, network services, if overused, may experience a loss of efficiency. Moreover, the availability of qualified manpower may diminish, and the shortage of qualified workers may lessen the effects of cost reductions. 


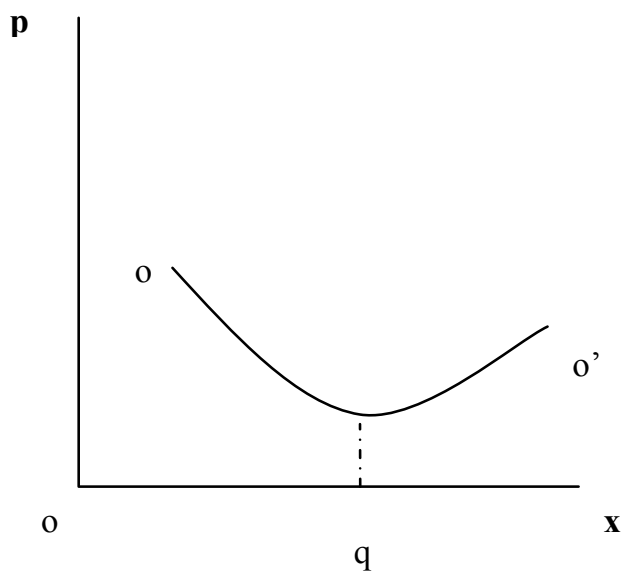

Figure 3: General function of the tourist industry supply.

It must also be pointed out that the enterprise pressure on service infrastructures, already bearing the burden of many users, compounds the difficulties faced by the entire industry.

The trend of the tourist industry supply, as a function of the produced quantity, is shown in Figure 3.

Here, the supply function curve, expressed by the formula

$$
\mathrm{P}=\mathrm{aq} \mathrm{q}^{2}+\mathrm{bq}+\mathrm{c}
$$

decreases to the quantity OQ. When the supply curve reaches this point, external and internal economies diminish. This phenomenon determines a supply trend which is the opposite of the trend that characterizes the same industry until the production reaches that level. Hence, this quantity leads to an increase in supply price.

\section{References}

[1] Sraffa P. (1925) Sulle relazioni tra costo e quantità prodotta, in Annali Econ. Vol. 2, 1925.

[2] Caffè F. (1990): Lezioni di politica economica, revised edition, Torino, Boringhieri.

[3] Kreps D.M., (1990), A Course in Microeconomic Theory, Prentice - Hall International, Hemel Hempstead, 1990;

[4] Palmerio G., (2008) Elementi di economia politica, Cacucci, Bari.

[5] Phelps E.S. (1985) Political Economy. An Introductory text, Norton \& Company, Inc. New York

[6] Alessandrini S., Passarelli F., (1999) Economia politica, Cisalpino, Milano 